\title{
Wide- and narrow-rim functionalised calix[4]arenes: synthesis and characterisation
}

\author{
Bernadette S. Creaven, ${ }^{\mathrm{a}}$ Tammy L. Gernon, ${ }^{\mathrm{a}, \mathrm{b}}$ John McGinley, ${ }^{\mathrm{b}, *}$ Ann-Marie Moore ${ }^{\mathrm{a}}$ \\ and Hans Toftlund ${ }^{\mathrm{c}}$ \\ ${ }^{a}$ Department of Science and Advanced Smart Materials Research Centre, Institute of Technology, Tallaght, Dublin 24, Ireland \\ ${ }^{\mathrm{b}}$ Department of Chemistry, National University of Ireland Maynooth, Maynooth, Co. Kildare, Ireland \\ ${ }^{\mathrm{c}}$ Department of Chemistry, University of Southern Denmark, DK-5230 Odense M, Denmark
}

Received 27 February 2006; revised 13 June 2006; accepted 29 June 2006

Available online 26 July 2006

\begin{abstract}
Functionalisation of calix[4]arene at both the wide and narrow rims leads to the formation of compounds containing bipyridyl, via an amide linkage, at the wide rim and having either a butyl chain, a benzyl group or an alkyl ester functionality at the narrow rim. All compounds were characterised using ${ }^{1} \mathrm{H}$ and ${ }^{13} \mathrm{C}$ NMR spectroscopies. Initial binding studies with $\mathrm{Ru}(\text { bipy })_{2} \mathrm{Cl}_{2}$ are reported.

(C) 2006 Elsevier Ltd. All rights reserved.
\end{abstract}

\section{Introduction}

Calix[4]arenes are macrocyclic molecules with unique three-dimensional structures. They belong to a larger family of calix $[n]$ arene molecules that is relatively old, and is generated from the chemical condensation of formaldehyde and phenol. ${ }^{1}$ When all four oxygen atoms point in the same direction, the macrocycle exhibits a bowl-shaped structure called the cone conformation. Functionalisation of the calix[4]arene is referred to as either narrow rim (previously called lower rim), if it occurs at the phenolic oxygen, or wide rim (previously called upper rim), if it occurs at the para position after the removal of p-tert-butyl groups (see Fig. 1).

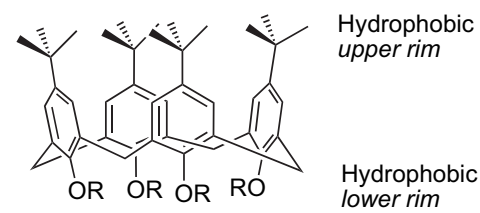

Figure 1. Structural formula of calix[4]arene.

Their controlled synthetic functionalisation and their versatile complexation properties ${ }^{1}$ allow the use of these compounds in supramolecular chemistry as molecular scaffolds for the construction of various receptors. They are frequently

Keywords: Calix[4]arene; Functionalisation; Synthesis; Amide linkage; NMR.

* Corresponding author. Tel.: +3531708 4615; fax: +3531708 3815;

e-mail: john.meginley@nuim.ie employed as platforms that permit functional groups to be orientated to provide well-organised cavities. The great interest in compounds of this type is primarily motivated by the ionophoric property of the narrow rim, which leads to applications in the area of cation binding and transport, as well as highly selective receptors and novel sensors for polyanionic species. ${ }^{1}$ This polyfunctional property stems from the fact that the narrow rim is relatively easy to chemically modify via well-established acid-base and nucleophilic reactions. The chemistry of the wide rim has not been fully exploited, and this can be explained by the relatively more difficult chemistry involved in its functionalisation; widerim modified derivatives are, for the most part, di-1,3- and tetrasubstituted species.

Furthermore, the functionalisation of calix[4]arenes at both the wide and narrow rims has not been widely discussed in the literature, ${ }^{1}$ though such molecules are desirable in the development of calixarene-based supramolecular structures. As part of a broad study of the interactions of various functional groups at both the wide and narrow rims, we have prepared and characterised some dipyridyl calix[4]arenes and their copper(I/II) complexes. ${ }^{2}$ This paper describes the functionalisation of the narrow rim with either $n$-butyl, benzyl or ester groups and the subsequent wide-rim derivatisation via amide groups containing a bipyridyl group.

\section{Results and discussion}

Both NMR and IR spectroscopies were used to characterise all the products synthesised. The NMR signals for the 
Table 1. Selected ${ }^{1} \mathrm{H}$ NMR data for compounds 1-13

\begin{tabular}{llll}
\hline Compound & $\mathrm{Ar}-\mathrm{H}$ & $-\mathrm{CH}_{2}-$ & $t$-Bu \\
\hline $\mathbf{1}$ & 7.04 & $4.23,3.49$ & 1.21 \\
$\mathbf{2}$ & $7.03,6.84$ & $4.31,3.28$ & $1.26,1.00$ \\
$\mathbf{3}$ & $7.03,6.83$ & $4.25,3.29$ & $1.27,0.98$ \\
$\mathbf{4}$ & $7.02,6.85$ & $4.43,3.30$ & $1.25,1.00$ \\
$\mathbf{5}$ & $8.03,6.96$ & $4.30,3.49$ & 1.06 \\
$\mathbf{6}$ & $8.03,6.89$ & $4.23,3.40$ & 1.01 \\
$\mathbf{7}$ & $8.02,7.07$ & $4.54,3.50$ & 1.11 \\
$\mathbf{8}$ & $6.90,6.45$ & $4.25,3.20$ & 1.15 \\
$\mathbf{9}$ & $6.84,6.42$ & $4.25,3.18$ & 1.04 \\
$\mathbf{1 0}$ & $6.97,6.32$ & $4.50,3.24$ & 1.16 \\
$\mathbf{1 1}$ & $7.40,7.00$ & $4.40,3.49$ & 1.10 \\
$\mathbf{1 2}$ & $7.40,6.96$ & $4.36,3.41$ & 1.06 \\
$\mathbf{1 3}$ & $7.39,7.01$ & $4.55,3.39$ & 1.12 \\
\hline
\end{tabular}

methylene bridges, aromatic protons and tert-butyl groups for all of the calix[4]arene derivatives are summarised in Table 1; complete data for all compounds are given in Section 4. Scheme 1 shows the synthetic approach chosen for the $n$-butyl, benzyl and ester derivatives.
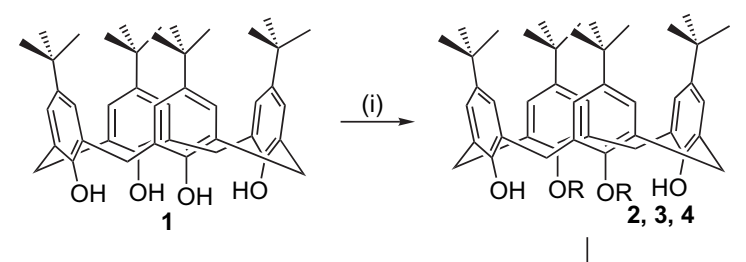

(ii)

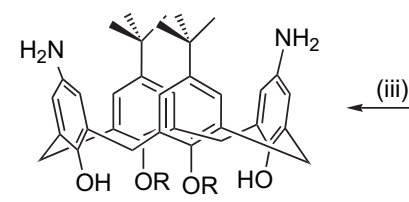

$8,9,10$

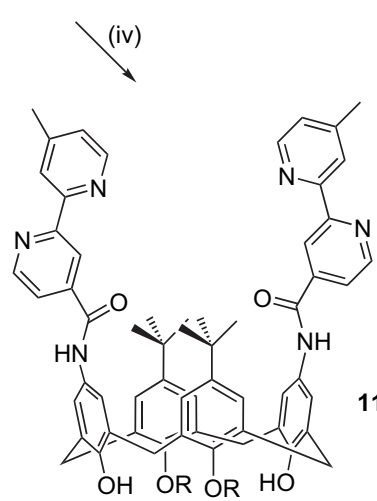

$11,12,13$

Scheme 1. Reagents and conditions: (i) $\mathrm{K}_{2} \mathrm{CO}_{3}$, appropriate halo-compound, MeCN, reflux $18 \mathrm{~h}$; (ii) $\mathrm{HNO}_{3}$, acetic acid, DCM, reflux $3 \mathrm{~h}$; (iii) $\mathrm{SnCl}_{2}, \mathrm{EtOH}$, reflux $12 \mathrm{~h}$; (iv) 4-methyl-4'-carboxylic acid-2,2'-bipyridine, DMT-MM, MeOH, reflux 4 h. $\mathrm{R}=n-\mathrm{C}_{4} \mathrm{H}_{9}$, benzyl or $\mathrm{CH}_{2} \mathrm{CO}_{2} \mathrm{Et}$.

The parent calix[4]arene $\mathbf{1}$ was reacted with potassium carbonate and the appropriate halo-compound (benzyl chloride, 1-bromo-butane or ethyl bromoacetate) in acetonitrile at reflux temperature to give the narrow-rim 1,3-disubstituted compounds 2, 3 and $\mathbf{4}$ in good yields. Compounds 2-4 show the expected NMR pattern, with two signals being observed for both the aromatic protons of the calix[4] arene and the tert-butyl groups, indicative of 1,3-disubstitution on the narrow rim of the calix[4]arene. Furthermore, the cone conformation of the derivatised calix[4]arenes is also confirmed by the presence of two sharp doublets at approximately 4.3 and $3.3 \mathrm{ppm}$ in each case.

The diprotected-calix[4]arene, with either the benzyl group (2), the $n$-butyl group (3) or the ester group (4), was then treated with concentrated nitric acid in acetic acid to give the dinitro-diprotected-calix[4]arenes 5, 6 and 7. In all cases, the nitro group replaces the tert-butyl group opposite the free $\mathrm{OH}$ group. The ${ }^{1} \mathrm{H}$ NMR spectra of compounds 5-7 showed several characteristic signals. The signal for the $\mathrm{OH}$ group shifts downfield from $\delta 8.00(3)$ and $7.15(4)$ to $\delta 8.66(5)$, 9.44 (6) and 8.94 (7); the $\mathrm{OH}$ signal for compound 2 is hidden under the signal for one of the benzyl protons at $\delta 7.35$. A large downfield shift is also observed for the aromatic proton on the phenyl ring to which the nitro group becomes attached (see Table 1). The signal for one of the tert-butyl groups is also lost, confirming the replacement of the tert-butyl group by the nitro group. Finally, the cone conformation of each calix [4] arene is also retained. Reinhoudt et al. describe similar shifts for the $\mathrm{OH}$ signals in their paper on the nitration of calix[4] arenes. ${ }^{3}$ One interesting point regarding the yields of the nitration reactions is that the nitration of the diester calix[4]arene (4) proceeds only in very low yield (17\% in our case and $24 \%$ in the literature ${ }^{3}$ ). The conclusion that can be drawn is that the ester group, and in particular the carbonyl group, is playing some unexpected role in the reaction, thereby causing the yield to decrease. Reinhoudt et al. ${ }^{3}$ suggest that the presence of electron donating groups on the narrow rim should enhance the nitration reaction but offer no explanation as to the low yield for this particular compound.

The dinitro compounds then underwent reduction with $\mathrm{Sn}(\mathrm{II}) \mathrm{Cl}_{2}$ in ethanol to give the diamino-diprotected-calix[4] arenes 8, 9 and 10, in a similar manner to that reported in the literature. ${ }^{4}$ These compounds are easily identified by the large upfield shift of the aromatic protons from, for example, $\delta 8.03$ and 6.89 in compound 5 (the dinitro-di-benzyl compound) to $\delta 6.84$ and 6.42 in compound 8 (the diaminodi-benzyl compound). This type of shift has been observed previously in various wide-rim amino-calix[4]arenes. ${ }^{4}$ Again, the presence of two doublets in the $4.5-3.0 \mathrm{ppm}$ region indicates cone conformation retention. The diaminocalix[4]arenes (8-10) were not particularly air or moisturestable but all decomposed to a sticky material when exposed to air, as a solid, for several hours. The ${ }^{1} \mathrm{H}$ NMR spectrum of the sticky material indicated that breakdown of the calix[4]arene was occurring. For this reason, all samples were only made prior to proceeding with the next reaction in Scheme 1.

Compounds 11, 12 and $\mathbf{1 3}$ were synthesised by reaction of the appropriate diamino-calix[4]arene with 4-methyl$4^{\prime}$-carboxylic acid-2,2'-bipyridine ${ }^{5}$ using 4-(4,6-dimethoxy-1,3,5-triazin-2-yl)-4-methyl-morpholinium chloride ${ }^{6}$ (DMT-MM) as condensing agent. The successful condensation of carboxylic acids and amines by DMT-MM in THF to give the corresponding amides in good yields was reported by Kunishima et al. ${ }^{6}$ The selective formation of carboxamides $(-\mathrm{CONH}-)$ in alcohol or water by a convenient one-step procedure, in which the condensing agent (DMT$\mathrm{MM})$ is simply added to a mixture of acids and amines, was also achieved successfully by the same group. ${ }^{7}$ The choice of DMT-MM as the base for this reaction was based on the fact that the workup in these cases was a simple 
filtration. DMT-MM also has the added advantage that the reaction conditions are very mild, that is, a 3-h stir in methanol. In all cases, the presence of the amide carbonyl group in the IR spectra was clearly seen at approximately $1670 \mathrm{~cm}^{-1}$ for the bipyridyl compounds $(\mathbf{1 1 - 1 3})$. The ${ }^{1} \mathrm{H}$ NMR spectra again showed that the cone conformation was retained in all cases. The $9.0-6.5 \mathrm{ppm}$ region of each spectrum contained many signals but in all cases there were no overlapping signals and all the signals were sharp and well-defined, making assignment straightforward. The use of an ${ }^{1} \mathrm{H}-{ }^{1} \mathrm{H}$ COSY spectrum further simplified the process, together with a COSY spectrum previously published by Hesek et al. ${ }^{8}$ The presence of a sharp singlet at $\delta 2.49$, due to the methyl group on the bipyridyl group, was a useful reference signal to indicate that attachment had taken place.

These bipyridyl calixarenes are potential building blocks for supramolecular structures as they should be able to bind transition metal centres at the wide rim. To test this theory, we decided to carry out an initial study of the reaction between cis-bis(2,2'-bipyridine)dichloro-ruthenium(II) $(\mathrm{Ru}-$ (bipy) ${ }_{2} \mathrm{Cl}_{2}$ ) and the calix[4]arene derivatives 11, 12 and 13. This consisted of carrying out the reaction, in each case, in ethanol at reflux temperature for $3 \mathrm{~h}$ followed by the addition of tetrabutylammonium hexafluorophosphate in order to precipitate a solid material. In all cases, orange/ brown coloured solids were obtained. TLC analysis on these complexes, using $\mathrm{CHCl}_{3} / \mathrm{MeOH}$ (9/1) as the solvent system, showed no sign of the starting calix[4]arene compounds. Preliminary characterisation of the ruthenium(II) complexes was carried out using only ${ }^{1} \mathrm{H}$ NMR spectroscopy. A more in-depth characterisation will be reported for all the complexes at a later date. The ${ }^{1} \mathrm{H}$ NMR spectra of the three ruthenium complexes were obtained and all showed a more complicated spectrum, particularly in the aromatic region, than that obtained for the starting calix[4]arene derivative. Figure 2 shows the ${ }^{1} \mathrm{H}$ NMR spectra of $\mathbf{1 3}$ prior to and after complexation with the ruthenium compound.

(a)

ppm 10

8

6

4

2

0

(b)

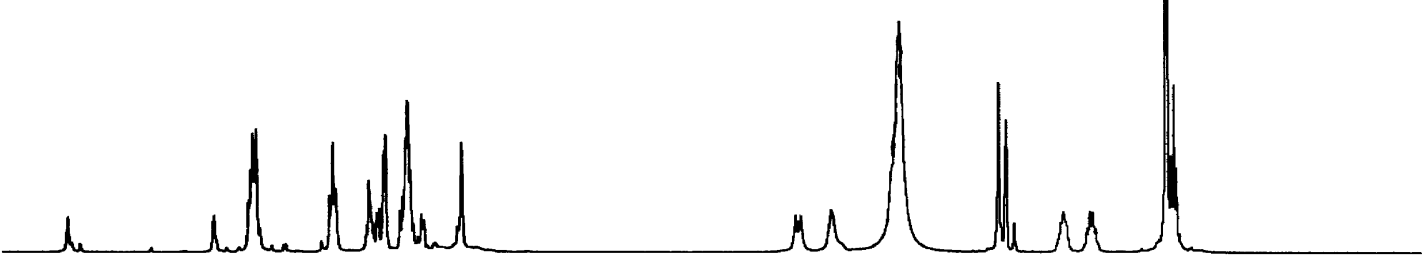

Figure 2. ${ }^{1} \mathrm{H}$ NMR spectra in $\mathrm{CDCl}_{3}$ of (a) $\mathbf{1 3}$ and (b) $\left[\mathbf{1 3} \cdot(\mathrm{Ru})_{2}\right]^{4+}$ complex. 
The resonance signals for the tert-butyl, ester/butyl/benzyl groups and the bipyridyl methyl group were clearly seen. Only one set of doublets was seen for the methylene bridges in all cases; the second set was covered by the DMSO signal. Because of the additional signals for the $\left[\mathrm{Ru}(\mathrm{bipy})_{3}\right]^{2+}$ moiety, only one aromatic signal at $7.10 \mathrm{ppm}$ was distinguished for the calixarene in the case of the butyl derivative (12); the second signal was under the signals for the $\left[\mathrm{Ru}(\mathrm{bipy})_{3}\right]^{2+}$ moiety itself. The $3-\mathrm{H}$ and $3^{\prime}-\mathrm{H}$ signals for the bipyridyl group attached to the calix [4] arene were easily distinguished in the proton spectrum, as they were singlet peaks; the rest of the spectra relating to the $\left[\mathrm{Ru}(\text { bipy })_{3}\right]^{2+}$ was complicated. Therefore, the attachment of this ruthenium moiety to the functionalised calix[4]arenes $\mathbf{1 1}, \mathbf{1 2}$ and $\mathbf{1 3}$ produced the desired $\left[\mathrm{Ru}(\text { bipy })_{3}\right]^{2+}$ moiety on the upper rim of the modified calix[4]arenes. The di-ruthenium complexes were all isolated as their hexafluorophosphate salts in good yields (78, 64 and 90\% using compounds 11, 12 and 13, respectively). From these preliminary reactions it can be seen that the di-ruthenium calix[4]arenes were easily isolated in acceptable yields.

\section{Conclusions}

The syntheses of calix[4]arenes, which are derivatised at both the wide (bipyridyl) and narrow rims (benzyl, butyl and ester groups), were carried out and the compounds were characterised by NMR and IR spectroscopies. Following 1,3-difunctionalisation of the narrow rim, the wide rim was nitrated, followed by reduction to the amine before condensation with the bipyridyl acid to form an amide group took place. All yields were moderate to good, except in the case of the dinitro-diester calix[4]arene (6) where the yield was very low. These bipyridyl calixarenes are potential building blocks for supramolecular structures. We have carried out some initial complexation reactions with $\mathrm{Ru}$ (bipy) ${ }_{2} \mathrm{Cl}_{2}$ and we are currently investigating further transition metal reactions based on these initial findings.

\section{Experimental}

\subsection{General}

${ }^{1} \mathrm{H}$ and ${ }^{13} \mathrm{C}$ NMR $(\delta$ ppm, $J \mathrm{~Hz}$ ) spectra were recorded on a JOEL JNM-LA300 FTNMR spectrometer using saturated $\mathrm{CDCl}_{3}$ solutions with $\mathrm{Me}_{4} \mathrm{Si}$ reference, unless indicated otherwise, with resolutions of $0.18 \mathrm{~Hz}$ and $0.01 \mathrm{ppm}$. Infrared spectra $\left(\mathrm{cm}^{-1}\right)$ were recorded as $\mathrm{KBr}$ discs or liquid films between $\mathrm{KBr}$ plates using a Nicolet Impact 410 FT-IR. All UV-vis spectra were recorded on a Shimadzu UV-160A spectrometer. Melting point analysis was carried out using a Stewart Scientific SMP 1 melting point apparatus and is uncorrected. Mass spectra were obtained using a Bruker-Esquire-LC_00050 electrospray ionisation mass spectrometer at positive polarity with cap-exit voltage of $167 \mathrm{~V}$. Spectra were recorded in the scan range of 50-2200 $\mathrm{m} / \mathrm{z}$ with a potential between 30 and $70 \mathrm{~V}$. Microanalysis was carried out at the Microanalytical Laboratory of either University College, Dublin or the National University of Ireland Cork. Standard Schlenk techniques were used throughout. Starting materials were commercially obtained and used without further purification. The syntheses of compounds 4-tert-butyl-calix[4]arene, 1, ${ }^{9}$ 5,11,17,23-tetratert-butyl-25,27-dibenzyloxy-calix[4]arene, $\mathbf{2},{ }^{10} 5,11,17,23$ tetra-tert-butyl-25,27-dibutoxycalix[4]-arene, $\mathbf{3},{ }^{2}$ 5,11,17,23tetra-tert-butyl-25,27-diethoxycarbonylmethoxycalix[4]arene, $4^{11}$ and 4-(4,6-dimethoxy-1,3,5-triazin-2-yl)-4-methyl-morpholinium chloride ${ }^{6}$ (DMT-MM) have been described in the literature previously.

\subsection{General synthesis of 2,3 and 4}

To a stirring suspension of 4-tert-butylcalix[4]arene (1, $3.1 \mathrm{mmol})$ and potassium carbonate $(7.7 \mathrm{mmol})$ in acetonitrile $(60 \mathrm{ml})$, under nitrogen, was added the appropriate halo-compound $(6.8 \mathrm{mmol})$ in acetonitrile $(10 \mathrm{ml})$, and the mixture was heated to reflux for $18 \mathrm{~h}$. After being cooled to room temperature, the suspension was filtered to remove inorganic salts and the filtrate was concentrated on a rotary evaporator to yield the appropriate compound.

4.2.1. 5,11,17,23-Tetra-tert-butyl-25,27-dibenzyloxycalix[4]arene, 2. ${ }^{10}$ White solid, yield $=72 \%$; $\mathrm{mp} \mathrm{216-}$ $218^{\circ} \mathrm{C}$ (lit. 216-220 ${ }^{\circ} \mathrm{C}$ ); $\nu_{\max }(\mathrm{KBr}) 3395(\mathrm{OH}) \mathrm{cm}^{-1} ; \delta_{\mathrm{H}}$ $\left(300 \mathrm{MHz} \mathrm{CDCl}_{3}\right): 7.64(4 \mathrm{H}, \mathrm{t}, J 6.5 \mathrm{~Hz}, \mathrm{Ph}-H), 7.42(4 \mathrm{H}$, d, J $6.5 \mathrm{~Hz}, \mathrm{Ph}-H), 7.35(2 \mathrm{H}, \mathrm{m}, \mathrm{Ph}-H), 7.03(4 \mathrm{H}, \mathrm{s}$, $\mathrm{Ar}-H), 6.83$ (4H, s, Ar- $H$ ), 5.05 (4H, s, OCH $\left.{ }_{2} \mathrm{Ph}\right), 4.25$ (4H, d, J $\left.13.0 \mathrm{~Hz}, \mathrm{Ar}-\mathrm{CH}_{\mathrm{a}} H_{\mathrm{b}}-\mathrm{Ar}\right), 3.29(4 \mathrm{H}, \mathrm{d}, J 13.0 \mathrm{~Hz}$, $\left.\mathrm{Ar}-\mathrm{CH}_{\mathrm{a}} \mathrm{H}_{\mathrm{b}}-\mathrm{Ar}\right), 1.27(18 \mathrm{H}, \mathrm{s}, t-B u), 0.98(18 \mathrm{H}, \mathrm{s}, t-B u)$.

4.2.2. 5,11,17,23-Tetra-tert-butyl-25,27-dibutoxycalix[4]arene, 3. ${ }^{2}$ White solid, yield $=45 \%$; mp $262-265{ }^{\circ} \mathrm{C}$ (lit. $\left.264-266^{\circ} \mathrm{C}\right) ; \nu_{\max }(\mathrm{KBr}) 3395(\mathrm{OH}) \mathrm{cm}^{-1} ; \delta_{\mathrm{H}}(300 \mathrm{MHz}$, $\left.\mathrm{CDCl}_{3}\right): 8.00(2 \mathrm{H}, \mathrm{s}, \mathrm{OH}), 7.03(4 \mathrm{H}, \mathrm{s}, \mathrm{Ar}-H), 6.84(4 \mathrm{H}, \mathrm{s}$, Ar-H), 4.31 (4H, d, J $\left.12.8 \mathrm{~Hz}, \mathrm{Ar}-\mathrm{CH}_{\mathrm{a}} \mathrm{H}_{\mathrm{b}}-\mathrm{Ar}\right), 3.97(4 \mathrm{H}, \mathrm{t}$, $\left.J 6.5 \mathrm{~Hz}, \mathrm{OCH}_{2} \mathrm{CH}_{2}\right), 3.28\left(4 \mathrm{H}, \mathrm{d}, J 12.8 \mathrm{~Hz}, \mathrm{Ar}-\mathrm{CH}_{\mathrm{a}} \mathrm{H}_{\mathrm{b}^{-}}\right.$ Ar), $2.02\left(4 \mathrm{H}, \mathrm{m}, \mathrm{CH}_{2}\right), 1.70\left(4 \mathrm{H}, \mathrm{m}, \mathrm{CH}_{2}\right), 1.26(18 \mathrm{H}, \mathrm{s}$, $t-B u), 1.08\left(6 \mathrm{H}, \mathrm{t}, J 7.4 \mathrm{~Hz}, \mathrm{CH}_{2} \mathrm{CH}_{3}\right), 1.00(18 \mathrm{H}, \mathrm{s}, t-\mathrm{Bu})$.

4.2.3. 5,11,17,23-Tetra-tert-butyl-25,27-diethoxycarbonylmethoxycalix[4]arene, 4. ${ }^{11}$ White solid, yield $=64 \%$; $\mathrm{mp} 184-186{ }^{\circ} \mathrm{C}$ (lit. $\left.182-184{ }^{\circ} \mathrm{C}\right) ; \nu_{\max }(\mathrm{KBr}) 3442(\mathrm{OH})$, $1747($ ester $\mathrm{C}=\mathrm{O}) \mathrm{cm}^{-1} ; \delta_{\mathrm{H}}\left(300 \mathrm{MHz}, \mathrm{CDCl}_{3}\right): 7.15(2 \mathrm{H}$, s, OH), $7.02(4 \mathrm{H}, \mathrm{s}, \mathrm{Ar}-H), 6.85(4 \mathrm{H}, \mathrm{s}, \mathrm{Ar}-H), 4.73(4 \mathrm{H}, \mathrm{s}$, $\left.\mathrm{OCH}_{2} \mathrm{CO}\right), 4.43\left(4 \mathrm{H}, \mathrm{d}, J 12.8 \mathrm{~Hz}, \mathrm{Ar}-\mathrm{CH}_{\mathrm{a}} H_{\mathrm{b}}-\mathrm{Ar}\right), 4.29$ $\left(4 \mathrm{H}, \mathrm{q}, J 6.5 \mathrm{~Hz}, \mathrm{COCH}_{2} \mathrm{CH}_{3}\right), 3.30(4 \mathrm{H}, \mathrm{d}, J 12.8 \mathrm{~Hz}, \mathrm{Ar}-$ $\left.\mathrm{CH}_{\mathrm{a}} \mathrm{H}_{\mathrm{b}}-\mathrm{Ar}\right), 1.33\left(6 \mathrm{H}, \mathrm{t}, J 7.3 \mathrm{~Hz}, \mathrm{CH}_{3}\right), 1.25(18 \mathrm{H}, \mathrm{s}$, $t-B u), 1.00(18 \mathrm{H}, \mathrm{s}, t-B u)$.

\subsection{General synthesis of 5, 6 and 7}

Diprotected calix[4]arene $\mathbf{2}, \mathbf{3}$ or 4 (9 mmol) was dissolved in a mixture of acetic acid $(40 \mathrm{ml})$ and dichloromethane $(40 \mathrm{ml})$. Concentrated nitric acid $(8 \mathrm{ml}, 90 \mathrm{mmol})$ was added dropwise over $10 \mathrm{~min}$ at $0{ }^{\circ} \mathrm{C}$. The reaction was kept at $0{ }^{\circ} \mathrm{C}$ for a further $15 \mathrm{~min}$ before being warmed to room temperature for $3 \mathrm{~h}$. The mixture was quenched by the addition of ice-water $(100 \mathrm{ml})$ and the organic layer was separated. The aqueous layer was then extracted with dichloromethane $(3 \times 30 \mathrm{ml})$. The organic layers were combined, dried with $\mathrm{MgSO}_{4}$ and then filtered. Removal of the solvent followed by recrystallisation from methanol yielded 5,6 or 7 , respectively. 
4.3.1. 5,17-Di-tert-butyl-11,23-dinitro-25,27-dibenzyloxycalix[4]arene, 5. Yellow solid, yield $=57 \%$. Found: $\mathrm{C}$, 74.24; $\mathrm{H}, 6.35 ; \mathrm{N}, 3.58$. Calcd for $\mathrm{C}_{50} \mathrm{H}_{50} \mathrm{~N}_{2} \mathrm{O}_{8}: \mathrm{C}, 74.42$; $\mathrm{H}, 6.25 ; \mathrm{N}, 3.47 ; \mathrm{mp} 220^{\circ} \mathrm{C}$ dec; $\nu_{\max }(\mathrm{KBr}) 3340(\mathrm{OH})$, $1520\left(\mathrm{NO}_{2}\right), 1320\left(\mathrm{NO}_{2}\right) \mathrm{cm}^{-1} ; \delta_{\mathrm{H}}\left(300 \mathrm{MHz}, \mathrm{CDCl}_{3}\right)$ : $8.86(2 \mathrm{H}, \mathrm{s}, \mathrm{OH}), 8.03(4 \mathrm{H}, \mathrm{s}, \mathrm{Ar}-\mathrm{H}), 7.61(4 \mathrm{H}, \mathrm{m}, \mathrm{Ph}-\mathrm{H})$, $7.46(4 \mathrm{H}, \mathrm{m}, \mathrm{Ph}-H), 7.39(2 \mathrm{H}, \mathrm{m}, \mathrm{Ph}-H), 6.89(4 \mathrm{H}, \mathrm{s}$, $\mathrm{Ar}-\mathrm{H}), 5.07\left(4 \mathrm{H}, \mathrm{s}, \mathrm{OCH}_{2} \mathrm{Ph}\right), 4.23(4 \mathrm{H}, \mathrm{d}, J 13.0 \mathrm{~Hz}, \mathrm{Ar}-$ $\left.\mathrm{CH}_{\mathrm{a}} H_{\mathrm{b}}-\mathrm{Ar}\right), 3.40\left(4 \mathrm{H}, \mathrm{d}, J 12.8 \mathrm{~Hz}, \mathrm{Ar}-\mathrm{CH}_{\mathrm{a}} \mathrm{H}_{\mathrm{b}}-\mathrm{Ar}\right), 1.01$ $(18 \mathrm{H}, \mathrm{s}, t-B u)$.

4.3.2. 5,17-Di-tert-butyl-11,23-dinitro-25,27-dibutoxycalix[4]arene, 6. Yellow solid, yield $=70 \%$. Found: C, 71.59; H, 7.37; N, 3.79. Calcd for $\mathrm{C}_{44} \mathrm{H}_{54} \mathrm{~N}_{2} \mathrm{O}_{8}$ : C, 71.52; $\mathrm{H}, 7.37 ; \mathrm{N}, 3.79 ; \mathrm{mp} 280^{\circ} \mathrm{C}$ dec; $\nu_{\max }(\mathrm{KBr}) 3285(\mathrm{OH})$, $1510\left(\mathrm{NO}_{2}\right), 1330\left(\mathrm{NO}_{2}\right) \mathrm{cm}^{-1} ; \delta_{\mathrm{H}}\left(300 \mathrm{MHz}, \mathrm{CDCl}_{3}\right)$ : $9.44(2 \mathrm{H}, \mathrm{s}, \mathrm{OH}), 8.03(4 \mathrm{H}, \mathrm{s}, \mathrm{Ar}-H), 6.96(4 \mathrm{H}, \mathrm{s}, \mathrm{Ar}-H)$, $4.30\left(4 \mathrm{H}, \mathrm{d}, J 12.8 \mathrm{~Hz}, \mathrm{Ar}-\mathrm{CH}_{\mathrm{a}} H_{\mathrm{b}}-\mathrm{Ar}\right), 4.00(4 \mathrm{H}, \mathrm{t}, J$ $\left.6.5 \mathrm{~Hz}, \mathrm{OCH}_{2} \mathrm{CH}_{2}\right), 3.49\left(4 \mathrm{H}, \mathrm{d}, J 12.8 \mathrm{~Hz}, \mathrm{Ar}-\mathrm{CH}_{\mathrm{a}} \mathrm{H}_{\mathrm{b}}-\mathrm{Ar}\right)$, $2.05\left(4 \mathrm{H}, \mathrm{m}, \mathrm{CH}_{2}\right), 1.68\left(4 \mathrm{H}, \mathrm{m}, \mathrm{CH}_{2}\right), 1.13(6 \mathrm{H}, \mathrm{t}, J$ $\left.7.4 \mathrm{~Hz}, \mathrm{CH}_{2} \mathrm{CH}_{3}\right), 1.06(18 \mathrm{H}, \mathrm{s}, t-\mathrm{Bu})$.

\subsubsection{5,17-Di-tert-butyl-11,23-dinitro-25,27-diethoxycar-} bonylmethoxycalix [4]arene, $7 .{ }^{3}$ Yellow solid, yield $=17 \%$; mp 190-192 ${ }^{\circ} \mathrm{C} ; \nu_{\max }(\mathrm{KBr}) 3360(\mathrm{OH}), 1752($ ester $\mathrm{C}=\mathrm{O})$, $1516\left(\mathrm{NO}_{2}\right), 1332\left(\mathrm{NO}_{2}\right) \mathrm{cm}^{-1} ; \delta_{\mathrm{H}}\left(300 \mathrm{MHz}, \mathrm{CDCl}_{3}\right): 8.94$ $(2 \mathrm{H}, \mathrm{s}, \mathrm{OH}), 8.02(4 \mathrm{H}, \mathrm{s}, \mathrm{Ar}-H), 7.07(4 \mathrm{H}, \mathrm{s}, \mathrm{Ar}-\mathrm{H}), 4.84(4 \mathrm{H}$, s, $\left.\mathrm{OCH}_{2} \mathrm{CO}\right), 4.54\left(4 \mathrm{H}, \mathrm{d}, J 12.8 \mathrm{~Hz}, \mathrm{Ar}-\mathrm{CH}_{\mathrm{a}} \mathrm{H}_{\mathrm{b}}-\mathrm{Ar}\right), 4.29$ $\left(4 \mathrm{H}, \mathrm{q}, J 6.8 \mathrm{~Hz}, \mathrm{COCH}_{2} \mathrm{CH}_{3}\right), 3.50(4 \mathrm{H}, \mathrm{d}, J 12.8 \mathrm{~Hz}, \mathrm{Ar}-$ $\left.\mathrm{CH}_{\mathrm{a}} \mathrm{H}_{\mathrm{b}}-\mathrm{Ar}\right), 1.37\left(6 \mathrm{H}, \mathrm{t}, J 7.4 \mathrm{~Hz}, \mathrm{CH}_{3}\right), 1.11(18 \mathrm{H}, \mathrm{s}, t-B u)$.

\subsection{General synthesis of 8,9 and 10}

To a stirred solution of the appropriate dinitro-calix[4]arene $\mathbf{8 , 9}$ or $10(1.4 \mathrm{mmol})$ in $25 \mathrm{ml}$ ethanol was added $\mathrm{SnCl}_{2}$ $(14 \mathrm{mmol})$. The reaction mixture was heated under nitrogen for $24 \mathrm{~h}$ and then quenched by pouring into ice-water $(100 \mathrm{ml})$. The $\mathrm{pH}$ was adjusted to $9-10$ using $5 \mathrm{M} \mathrm{KOH}$. The aqueous phase was then extracted with dichloromethane $(3 \times 30 \mathrm{ml})$ and the combined organic phases were dried over $\mathrm{MgSO}_{4}$. After filtration, the evaporation of the solvent under reduced pressure yielded the diamino-calix[4]arene, which was used immediately without further purification. No elemental analyses were obtained for either $\mathbf{8 , 9}$ or $\mathbf{1 0}$, as the samples decomposed while being sent for microanalysis.

4.4.1. 5,17-Di-tert-butyl-11,23-diamino-25,27-dibenzyloxycalix[4]arene, 8. Dark pink solid, yield $=55 \%$; mp $200{ }^{\circ} \mathrm{C}$ dec; $\nu_{\max }(\mathrm{KBr}) 3360(\mathrm{OH}), 1615\left(\mathrm{NH}_{2}\right) \mathrm{cm}^{-1} ; \delta_{\mathrm{H}}$ $\left(300 \mathrm{MHz}, \mathrm{CDCl}_{3}\right): 7.60(4 \mathrm{H}, \mathrm{m}, \mathrm{Ph}-H), 7.38(4 \mathrm{H}, \mathrm{d}$, $J 6.8 \mathrm{~Hz}, \mathrm{Ph}-H), 7.37(2 \mathrm{H}, \mathrm{m}, \mathrm{Ph}-H), 6.87(2 \mathrm{H}, \mathrm{s}, \mathrm{OH})$, $6.84(4 \mathrm{H}, \mathrm{s}, \operatorname{Ar}-H), 6.42(4 \mathrm{H}, \mathrm{s}, \operatorname{Ar}-H), 4.98(4 \mathrm{H}, \mathrm{s}$, $\left.\mathrm{OCH}_{2} \mathrm{Ph}\right), 4.25\left(4 \mathrm{H}, \mathrm{d}, J 12.8 \mathrm{~Hz}, \mathrm{Ar}-\mathrm{CH}_{\mathrm{a}} \mathrm{H}_{\mathrm{b}}-\mathrm{Ar}\right), 3.18$ $\left(4 \mathrm{H}, \mathrm{d}, J 12.8 \mathrm{~Hz}, \mathrm{Ar}-\mathrm{CH}_{\mathrm{a}} \mathrm{H}_{\mathrm{b}}-\mathrm{Ar}\right), 1.04(18 \mathrm{H}, \mathrm{s}, t-\mathrm{Bu})$.

4.4.2. 5,17-Di-tert-butyl-11,23-diamino-25,27-dibutoxycalix[4]arene, 9. Dark pink solid, yield $=81 \%$; mp 140$142^{\circ} \mathrm{C} ; \nu_{\max }(\mathrm{KBr}) 3365(\mathrm{OH}), 1619\left(\mathrm{NH}_{2}\right) \mathrm{cm}^{-1} ; \delta_{\mathrm{H}}$ $\left(300 \mathrm{MHz}, \mathrm{CDCl}_{3}\right): 7.68(2 \mathrm{H}, \mathrm{s}, \mathrm{OH}), 6.90(4 \mathrm{H}, \mathrm{s}, \mathrm{Ar}-H)$, $6.45(4 \mathrm{H}, \mathrm{s}, \mathrm{Ar}-H), 4.25\left(4 \mathrm{H}, \mathrm{d}, J 12.8 \mathrm{~Hz}, \mathrm{Ar}-\mathrm{CH}_{\mathrm{a}} H_{\mathrm{b}}-\mathrm{Ar}\right)$, $3.89\left(4 \mathrm{H}, \mathrm{t}, J 6.5 \mathrm{~Hz}, \mathrm{OCH}_{2} \mathrm{CH}_{2}\right), 3.20(4 \mathrm{H}, \mathrm{d}, J 12.8 \mathrm{~Hz}$, Ar- $\left.\mathrm{CH}_{\mathrm{a}} \mathrm{H}_{\mathrm{b}}-\mathrm{Ar}\right), 2.08\left(4 \mathrm{H}, \mathrm{m}, \mathrm{CH}_{2}\right), 1.64\left(4 \mathrm{H}, \mathrm{m}, \mathrm{CH}_{2}\right)$, $1.15(18 \mathrm{H}, \mathrm{s}, t-\mathrm{Bu}), 1.09\left(6 \mathrm{H}, \mathrm{t}, J 7.4 \mathrm{~Hz}, \mathrm{CH}_{2} \mathrm{CH}_{3}\right)$.
4.4.3. 5,17-Di-tert-butyl-11,23-diamino-25,27-diethoxycarbonylmethoxycalix[4]arene, 10. Pink solid, yield= 88\%; mp $200{ }^{\circ} \mathrm{C} \mathrm{dec;} \nu_{\max }(\mathrm{KBr}) 3345(\mathrm{OH}), 1618\left(\mathrm{NH}_{2}\right)$, $1752($ ester $\mathrm{C}=\mathrm{O}) \mathrm{cm}^{-1} ; \delta_{\mathrm{H}}\left(300 \mathrm{MHz}, \mathrm{CDCl}_{3}\right): 7.04(2 \mathrm{H}$, s, $\mathrm{OH}), 6.97(4 \mathrm{H}, \mathrm{s}, \mathrm{Ar}-H), 6.32(4 \mathrm{H}, \mathrm{s}, \mathrm{Ar}-H), 4.83(4 \mathrm{H}, \mathrm{s}$, $\left.\mathrm{OCH}_{2} \mathrm{CO}\right), 4.50\left(4 \mathrm{H}, \mathrm{d}, J 12.8 \mathrm{~Hz}, \mathrm{Ar}-\mathrm{CH}_{\mathrm{a}} \mathrm{H}_{\mathrm{b}}-\mathrm{Ar}\right), 4.30$ $\left(4 \mathrm{H}, \mathrm{q}, J 6.8 \mathrm{~Hz}, \mathrm{COCH}_{2} \mathrm{CH}_{3}\right), 3.24(4 \mathrm{H}, \mathrm{d}, J 12.8 \mathrm{~Hz}, \mathrm{Ar}-$ $\left.\mathrm{CH}_{\mathrm{a}} \mathrm{H}_{\mathrm{b}}-\mathrm{Ar}\right), 1.23\left(6 \mathrm{H}, \mathrm{t}, J 7.4 \mathrm{~Hz}, \mathrm{CH}_{3}\right), 1.16(18 \mathrm{H}, \mathrm{s}, t-B u)$.

\subsection{General synthesis of 11,12 and 13}

To a methanol solution $(20 \mathrm{ml})$ of diamino-calix[4]arene $\mathbf{8 , 9}$ or $10(0.15 \mathrm{mmol})$ and 4 -methyl-4'-carboxylic acid-2,2'-bipyridine $(0.31 \mathrm{mmol})$ was added DMT-MM $(0.33 \mathrm{mmol})$. The mixture was stirred under nitrogen for $3 \mathrm{~h}$. Over the course of the reaction, a solid, which is the product, precipitated. On cooling, the solid was filtered and dried.

4.5.1. 5,17-Di-tert-butyl-11,23-bis $\left(2,2^{\prime}\right.$-bipyridine4-methyl-4' -carboxyamido)-25,27-dibenzyloxy-calix[4]arene, 11. Red/pink solid, yield $=32 \%$. Found: $\mathrm{C}, 77.85 ; \mathrm{H}$, 6.05; N, 7.24. Calcd for $\mathrm{C}_{74} \mathrm{H}_{70} \mathrm{~N}_{6} \mathrm{O}_{6}: \mathrm{C}, 78.01 ; \mathrm{H}, 6.19 ; \mathrm{N}$, 7.38; mp 179-180 ${ }^{\circ} \mathrm{C}$; $\nu_{\max }(\mathrm{KBr}) 3368(\mathrm{OH}), 1669$ (amide $\mathrm{C}=\mathrm{O}) \mathrm{cm}^{-1} ; \quad \delta_{\mathrm{H}}\left(300 \mathrm{MHz}, \mathrm{CDCl}_{3}\right): 8.85 \quad(2 \mathrm{H}, \mathrm{d}, J$ $6.8 \mathrm{~Hz}, 6-\mathrm{H}), 8.73(2 \mathrm{H}, \mathrm{s}, 3-\mathrm{H}), 8.58\left(2 \mathrm{H}, \mathrm{d}, J 7.8 \mathrm{~Hz}, 6^{\prime}-\right.$ H), $8.31\left(2 \mathrm{H}, \mathrm{s}, 3^{\prime}-\mathrm{H}\right), 8.06(2 \mathrm{H}, \mathrm{s}, \mathrm{OH}), 7.89(2 \mathrm{H}, \mathrm{t}, J$ $7.6 \mathrm{~Hz}, 5-\mathrm{H}), 7.61(4 \mathrm{H}, \mathrm{m}, \mathrm{Ph}-H), 7.40(4 \mathrm{H}, \mathrm{s}, \mathrm{Ar}-\mathrm{H}), 7.38$ $(6 \mathrm{H}, \mathrm{m}, \mathrm{Ph}-H), 7.20\left(2 \mathrm{H}, \mathrm{d}, J 7.8 \mathrm{~Hz}, 5^{\prime}-\mathrm{H}\right), 6.90(4 \mathrm{H}, \mathrm{s}$, $\mathrm{Ar}-H), 5.06\left(4 \mathrm{H}, \mathrm{s}, \mathrm{OCH}_{2} \mathrm{Ph}\right), 4.32(4 \mathrm{H}, \mathrm{d}, J 13.3 \mathrm{~Hz}, \mathrm{Ar}-$ $\left.\mathrm{CH}_{\mathrm{a}} \mathrm{H}_{\mathrm{b}}-\mathrm{Ar}\right), 3.34\left(4 \mathrm{H}, \mathrm{d}, J 13.3 \mathrm{~Hz}, \mathrm{Ar}-\mathrm{CH}_{\mathrm{a}} \mathrm{H}_{\mathrm{b}}-\mathrm{Ar}\right), 2.46$ $\left(6 \mathrm{H}, \mathrm{s}, \mathrm{CH}_{3}\right), 1.03(18 \mathrm{H}, \mathrm{s}, t-\mathrm{Bu})$; ESMS: $\mathrm{m} / \mathrm{z} 1140.35$ $\left(\mathbf{1 1}+\mathrm{H}^{+}\right) ; \mathrm{C}_{74} \mathrm{H}_{71} \mathrm{~N}_{6} \mathrm{O}_{6}$ requires 1140.39; $1162.35\left(11+\mathrm{Na}^{+}\right)$; $\mathrm{C}_{74} \mathrm{H}_{70} \mathrm{NaN}_{6} \mathrm{O}_{6}$ requires 1162.37 .

4.5.2. 5,17-Di-tert-butyl-11,23-bis(2,2'-bipyridine-4methyl-4' -carboxyamido)-25,27-dibutoxy-calix[4]arene, 12. Cream solid, yield $=53 \%$. Found: $\mathrm{C}, 76.09 ; \mathrm{H}, 6.82 ; \mathrm{N}$, 7.96. Calcd for $\mathrm{C}_{68} \mathrm{H}_{74} \mathrm{~N}_{6} \mathrm{O}_{6}$ : C, 76.23; H, 6.96; N, 7.84; mp $185-187^{\circ} \mathrm{C} ; \nu_{\max }(\mathrm{KBr}) 3430(\mathrm{OH}), 1672$ (amide $\mathrm{C}=\mathrm{O}) \mathrm{cm}^{-1} ; \delta_{\mathrm{H}}\left(300 \mathrm{MHz}, \mathrm{CDCl}_{3}\right): 8.85(2 \mathrm{H}, \mathrm{d}, J 6.8 \mathrm{~Hz}$, 6-H), $8.71(2 \mathrm{H}, \mathrm{s}, 3-\mathrm{H}), 8.56\left(2 \mathrm{H}, \mathrm{d}, J 5.8 \mathrm{~Hz}, 6^{\prime}-\mathrm{H}\right), 8.25(2 \mathrm{H}$, $\left.\mathrm{s}, 3^{\prime}-\mathrm{H}\right), 8.10(2 \mathrm{H}, \mathrm{s}, \mathrm{OH}), 7.86(2 \mathrm{H}, \mathrm{t}, J 7.6 \mathrm{~Hz}, 5-\mathrm{H}), 7.40$ $(4 \mathrm{H}, \mathrm{s}, \mathrm{Ar}-\mathrm{H}), 7.20\left(2 \mathrm{H}, \mathrm{d}, J 6.2 \mathrm{~Hz}, 5^{\prime}-\mathrm{H}\right), 6.96(4 \mathrm{H}, \mathrm{s}, \mathrm{Ar}-$ $H), 4.36\left(4 \mathrm{H}, \mathrm{d}, J 12.8 \mathrm{~Hz}, \mathrm{Ar}-\mathrm{CH}_{\mathrm{a}} H_{\mathrm{b}}-\mathrm{Ar}\right), 4.01(4 \mathrm{H}, \mathrm{t}, J$ $\left.6.5 \mathrm{~Hz}, \mathrm{OCH}_{2} \mathrm{CH}_{2}\right), 3.41\left(4 \mathrm{H}, \mathrm{d}, J 12.8 \mathrm{~Hz}, \mathrm{Ar}-\mathrm{CH}_{\mathrm{a}} \mathrm{H}_{\mathrm{b}}-\mathrm{Ar}\right)$, $2.42\left(6 \mathrm{H}, \mathrm{s}, \mathrm{CH}_{3}\right), 2.06\left(4 \mathrm{H}, \mathrm{m}, \mathrm{CH}_{2}\right), 1.68\left(4 \mathrm{H}, \mathrm{m}, \mathrm{CH}_{2}\right)$, $1.09\left(6 \mathrm{H}, \mathrm{t}, J 7.4 \mathrm{~Hz}, \mathrm{CH}_{2} \mathrm{CH}_{3}\right), 1.06(18 \mathrm{H}, \mathrm{s}, t-\mathrm{Bu})$; ESMS: $m / z \quad 1071.35\left(\mathbf{1 2}+\mathrm{H}^{+}\right) ; \mathrm{C}_{68} \mathrm{H}_{75} \mathrm{~N}_{6} \mathrm{O}_{6}$ requires 1071.36; 1093.34 $\left(\mathbf{1 2}+\mathrm{Na}^{+}\right) ; \mathrm{C}_{68} \mathrm{H}_{74} \mathrm{NaN}_{6} \mathrm{O}_{6}$ requires 1093.34.

4.5.3. 5,17-Di-tert-butyl-11,23-bis(2,2'-bipyridine-4methyl-4' -carboxyamido)-25,27-diethoxycarbonyl-methoxycalix [4] arene, 13. Pale pink solid, yield $=51 \%$. Found: $\mathrm{C}, 72.44 ; \mathrm{H}, 6.35 ; \mathrm{N}, 7.65$. Calcd for $\mathrm{C}_{68} \mathrm{H}_{70} \mathrm{~N}_{6} \mathrm{O}_{10}$ : C, $72.19 ; \mathrm{H}, 6.24 ; \mathrm{N}, 7.43 ; \mathrm{mp} 218-221{ }^{\circ} \mathrm{C} ; \nu_{\max }(\mathrm{KBr}) 3416$ $(\mathrm{OH}), 1742$ (ester $\mathrm{C}=\mathrm{O}$ ), 1670 (amide $\mathrm{C}=\mathrm{O}) \mathrm{cm}^{-1} ; \delta_{\mathrm{H}}$ $\left(300 \mathrm{MHz}, \mathrm{CDCl}_{3}\right): 8.81(2 \mathrm{H}, \mathrm{d}, J 7.2 \mathrm{~Hz}, 6-\mathrm{H}), 8.52(2 \mathrm{H}$, $\left.\mathrm{d}, J 7.2 \mathrm{~Hz}, 6^{\prime}-\mathrm{H}\right), 8.26(2 \mathrm{H}, \mathrm{s}, 3-\mathrm{H}), 7.82(2 \mathrm{H}, \mathrm{d}, J 7.2 \mathrm{~Hz}$, $5-\mathrm{H}), 7.58\left(2 \mathrm{H}, \mathrm{s}, 3^{\prime}-\mathrm{H}\right), 7.57(2 \mathrm{H}, \mathrm{s}, \mathrm{OH}), 7.39(4 \mathrm{H}, \mathrm{s}, \mathrm{Ar}-$ $H), 7.18\left(2 \mathrm{H}, \mathrm{d}, J 7.2 \mathrm{~Hz}, 5^{\prime}-\mathrm{H}\right), 7.01(4 \mathrm{H}, \mathrm{s}, \mathrm{Ar}-H), 4.81$ $\left(4 \mathrm{H}, \mathrm{s}, \mathrm{OCH}_{2} \mathrm{CO}\right), 4.55\left(4 \mathrm{H}, \mathrm{d}, J 12.8 \mathrm{~Hz}, \mathrm{Ar}-\mathrm{CH}_{\mathrm{a}} \mathrm{H}_{\mathrm{b}}-\mathrm{Ar}\right)$, $4.34\left(4 \mathrm{H}, \mathrm{q}, J 6.9 \mathrm{~Hz}, \mathrm{COCH}_{2} \mathrm{CH}_{3}\right), 3.39(4 \mathrm{H}, \mathrm{d}, J$ $\left.12.8 \mathrm{~Hz}, \mathrm{Ar}-\mathrm{CH}_{\mathrm{a}} \mathrm{H}_{\mathrm{b}}-\mathrm{Ar}\right), 2.44\left(6 \mathrm{H}, \mathrm{s}, \mathrm{CH}_{3}\right), 1.35(6 \mathrm{H}, \mathrm{t}, J$ 
$\left.7.4 \mathrm{~Hz}, \mathrm{CH}_{2} \mathrm{CH}_{3}\right), 1.12(18 \mathrm{H}, \mathrm{s}, t-\mathrm{Bu})$; ESMS: $\mathrm{m} / z 1132.35$ $\left(\mathbf{1 3}+\mathrm{H}^{+}\right) ; \mathrm{C}_{68} \mathrm{H}_{75} \mathrm{~N}_{6} \mathrm{O}_{6}$ requires $1132.33 ; 1154.29\left(13+\mathrm{Na}^{+}\right)$; $\mathrm{C}_{68} \mathrm{H}_{74} \mathrm{NaN}_{6} \mathrm{O}_{6}$ requires 1154.31.

\subsection{General synthesis of complexation reactions of 11,12 and 13}

A solution of the appropriate calix[4]arene derivative $(0.078 \mathrm{mmol})$ and $\left[\mathrm{Ru}(\text { bipy })_{2}(\mathrm{Cl})_{2}\right](0.156 \mathrm{mmol})$ in ethanol $(20 \mathrm{ml})$ was heated to reflux for $3 \mathrm{~h}$ under nitrogen. After the reaction cooled to room temperature, $10 \mathrm{ml}$ of a saturated tetrabutylammonium hexafluorophosphate $\left(\mathrm{TBAPF}_{6}\right)$ solution was added, resulting in precipitation of the product as an orange/brown powder. The product was filtered, air dried for $24 \mathrm{~h}$ and collected.

4.6.1. $11+\mathbf{R u}(\text { bipy })_{2}\left(\mathbf{P F}_{\mathbf{6}}\right)_{2}$. Orange/brown solid, yield $=$ $78 \%, \delta_{\mathrm{H}}\left(300 \mathrm{MHz}, \mathrm{DMSO}-d_{6}\right): 10.40(2 \mathrm{H}, \mathrm{s}, \mathrm{OH}), 9.14$ (2H, s, H-3), 8.96-8.88 (4H, m, bipy H-3), 8.20-8.17 (4H, m, bipy H-4), 7.91 (2H, s, H-3'), 7.84-7.77 (6H, m, bipy H-5), $7.62(4 \mathrm{H}, \mathrm{m}, \mathrm{Ph}-H), 7.59-7.49$ (6H, m, bipy H-6), $7.44(6 \mathrm{H}, \mathrm{m}, \mathrm{Ph}-H), 7.09(2 \mathrm{H}, \mathrm{s}, \operatorname{Ar}-H), 5.06(4 \mathrm{H}, \mathrm{s}$, $\left.\mathrm{OCH}_{2} \mathrm{Ph}\right), 4.38\left(4 \mathrm{H}, \mathrm{d}, J 12.8 \mathrm{~Hz}, \mathrm{Ar}-\mathrm{CH}_{\mathrm{a}} \mathrm{H}_{\mathrm{b}}-\mathrm{Ar}\right), 2.48$ $\left(6 \mathrm{H}, \mathrm{s}, \mathrm{CH}_{3}\right), 1.03(18 \mathrm{H}, \mathrm{s}, t-B u)$.

4.6.2. $12+\mathbf{R u}(\text { bipy })_{2}\left(\mathbf{P F}_{6}\right)_{2}$. Orange/brown solid, yield $=$ $90 \%, \delta_{\mathrm{H}}\left(300 \mathrm{MHz}, \mathrm{DMSO}-d_{6}\right): 10.58(2 \mathrm{H}, \mathrm{s}, \mathrm{OH}), 9.20$ (2H, s, H-3), 8.99-8.84 (4H, m, bipy H-3), 8.22-8.17 (4H, m, bipy H-4), $7.88\left(2 \mathrm{H}, \mathrm{s}, \mathrm{H}-3^{\prime}\right), 7.82-7.75(6 \mathrm{H}, \mathrm{m}$, bipy H-5), 7.63-7.47 (6H, m, bipy H-6), $7.11(2 \mathrm{H}, \mathrm{s}, \mathrm{Ar}-\mathrm{H})$, $4.29\left(4 \mathrm{H}, \mathrm{d}, J 12.3 \mathrm{~Hz}, \operatorname{Ar}-\mathrm{CH}_{\mathrm{a}} H_{\mathrm{b}}-\mathrm{Ar}\right), 3.99(4 \mathrm{H}, \mathrm{m}$, $\left.\mathrm{OCH}_{2}\right), 2.57\left(6 \mathrm{H}, \mathrm{s}, \mathrm{CH}_{3}\right), 2.02\left(4 \mathrm{H}, \mathrm{m}, \mathrm{CH}_{2}\right), 1.80(4 \mathrm{H}$, $\left.\mathrm{m}, \mathrm{CH}_{2}\right), 1.16(18 \mathrm{H}, \mathrm{s}, t-\mathrm{Bu}), 1.09\left(6 \mathrm{H}, \mathrm{t}, J 7.3 \mathrm{~Hz}, \mathrm{CH}_{2} \mathrm{CH}_{3}\right)$.

4.6.3. $13+\mathbf{R u}(\text { bipy })_{2}\left(\mathbf{P F}_{6}\right)_{2}$. Orange/brown solid, yield $=$ $64 \%, \delta_{\mathrm{H}}\left(300 \mathrm{MHz}, \mathrm{DMSO}-d_{6}\right): 10.30(2 \mathrm{H}, \mathrm{s}, \mathrm{OH}), 9.10$ (2H, s, H-3), 8.86-8.81 (4H, m, bipy H-3), 8.20-8.16 (4H, m, bipy H-4), $7.92\left(2 \mathrm{H}, \mathrm{s}, \mathrm{H}-3^{\prime}\right), 7.87-7.72(6 \mathrm{H}, \mathrm{m}$, bipy H-5), 7.60-7.47 (6H, m, bipy H-6), $7.42(2 \mathrm{H}, \mathrm{s}, \mathrm{Ar}-\mathrm{H})$, $7.10(2 \mathrm{H}, \mathrm{s}, \mathrm{Ar}-\mathrm{H}), 4.86\left(4 \mathrm{H}, \mathrm{s}, \mathrm{OCH}_{2} \mathrm{CO}\right), 4.47(4 \mathrm{H}, \mathrm{d}, J$ $\left.12.8 \mathrm{~Hz}, \quad \operatorname{Ar}-\mathrm{CH}_{\mathrm{a}} H_{\mathrm{b}}-\mathrm{Ar}\right), \quad 4.30 \quad(4 \mathrm{H}, \quad \mathrm{q}, \quad J \quad 6.9 \mathrm{~Hz}$, $\left.\mathrm{COCH}_{2} \mathrm{CH}_{3}\right), 2.52\left(6 \mathrm{H}, \mathrm{s}, \mathrm{CH}_{3}\right), 1.34(6 \mathrm{H}, \mathrm{t}, J 6.9 \mathrm{~Hz}$, $\left.\mathrm{CH}_{2} \mathrm{CH}_{3}\right), 1.13(18 \mathrm{H}, \mathrm{s}, \mathrm{t}-\mathrm{Bu})$.

\section{Acknowledgements}

We are grateful to Enterprise Ireland for International Collaboration grants for T.L.G. and A.-M.M. and
Postgraduate R\&D Skills programme (Technological Sector Research, Strand I) for financial assistance. We also thank Maurice Burke for running the mass spectra.

\section{References and notes}

1. (a) Asfari, Z.; Böhmer, V.; Harrowfield, J.; Vicens, J. Calixarene 2001; Kluwer Academic: Dordrecht, 2001; (b) Mandolini, L.; Ungaro, R. Calixarene in Action; Imperial College: London, 2000; (c) Gutsche, C. D. Calixarenes Revisited: Monographs in Supramolecular Chemistry; Royal Society of Chemistry: London, 1998; (d) Vicens, J.; Böhmer, V. Calixarenes, a Versatile Class of Macrocyclic Compounds; Kluwer Academic: Dordrecht, 1991; (e) Gutsche, C. D. Calixarenes: Monographs in Supramolecular Chemistry; Royal Society of Chemistry: London, 1989.

2. Creaven, B. S.; Gernon, T. L.; McCormac, T.; McGinley, J.; Moore, A.-M.; Toftlund, H. Inorg. Chim. Acta 2005, 358, 2661-2670.

3. Verboom, W.; Durie, A.; Egberink, R. J. M.; Asfari, Z.; Reinhoudt, D. N. J. Org. Chem. 1992, 57, 1313-1318.

4. (a) Danila, C.; Bolte, M.; Böhmer, V. Org. Biomol. Chem. 2005, 3, 172-184; (b) Webber, P. R. A.; Beer, P. D. Dalton Trans. 2003, 2249-2252; (c) Pelizzi, N.; Casnati, A.; Friggeri, A.; Ungaro, R. J. Chem. Soc., Perkin Trans. 2 1998, 1307-1311.

5. McCafferty, D. G.; Bishop, B. M.; Wall, C. G.; Hughes, S. G.; Macklenberg, S. L.; Meyer, T. J.; Erickson, B. W. Tetrahedron 1995, 51, 1093-1106.

6. Kunishima, M.; Kawachi, C.; Morita, J.; Terao, K.; Iwasaka, F.; Tani, S. Tetrahedron 1999, 55, 13159-13170.

7. Kunishima, M.; Kawachi, C.; Hioki, K.; Terao, K.; Tani, S. Tetrahedron 2001, 57, 1551-1558.

8. Hesek, D.; Inoue, Y.; Everitt, S. R. L.; Kunieda, M.; Ishida, H.; Drew, M. G. B. Tetrahedron: Asymmetry 1998, 9, 40894097.

9. Gutsche, C. D.; Johnston, D. E., Jr.; Stewart, D. R. J. Org. Chem. 1999, 64, 3747-3750.

10. (a) Dijkstra, P. J.; Brunink, J. A. J.; Bugge, K.-E.; Reinhoudt, D. N.; Harlema, S.; Ungaro, R.; Ugozzoli, F.; Ghidini, E. J. Am. Chem. Soc. 1989, 111, 7567-7575; (b) Gutsche, C. D.; Reddy, P. A. J. Org. Chem. 1991, 56, 4783-4791.

11. Collins, E. M.; McKervey, M. A.; Harris, S. J. J. Chem. Soc., Perkin Trans. 1 1989, 372-374. 